\title{
An Empirical Model to Evaluate SPM Concentration in a Colliery Area
}

\author{
Bindhu Lal \\ Department of Civil Engineering,Birla Institute of Technology, India
}

Copyright $@ 2015$ Horizon Research Publishing All rights reserved.

\begin{abstract}
Jharkhand, a state in India is rich in minerals particularly coal. Large number of mines is excavated here. Opening of new mines and expanding existing mines causes air pollution. The main pollutants emitted are suspended particulate matter, oxides of nitrogen, sulphur dioxide and carbon dioxide. In this paper empirical models are developed to calculate SPM concentration in terms of $\mathrm{NO}_{x}$ concentrations and $\mathrm{SO}_{2}$ concentrations. It has been seen that there is a good linear relationship between hourly SPM and $\mathrm{NO}_{\mathrm{x}}$ concentrations and also between $\mathrm{SPM}$ and $\mathrm{SO}_{2}$ concentrations.
\end{abstract}

Keywords SPM Concentration, $\mathrm{SO}_{2}$ Concentration, $\mathrm{NO}_{\mathrm{x}}$ Concentration. Empirical Model

\section{Introduction}

Jharkhand is a mineral rich state in India. It has lot of deposits of minerals like iron, manganese, coal etc. Availability of commercial energy at affordable price is critical for industrial development of India. In the present scenario coal remains the cheap and abundantly available source for commercial energy. Increase in production will be achieved through opening new mines and expanding existing mines. Hence lots of mining operations are carried out in Jharkhand.

Air Quality Modeling is an attempt to predict or simulate the ambient concentrations of contaminants in the atmosphere.Many empirical and polynomial models have already been employed for estimating pollutant concentrations (Dastoor and Pudykiewicz, 1996; Binkowski and Ching, 1996; Stalbones et al., 1998; Cohn et al., 2001; Vardoulakis et al., 2003).. Karim M.M. and Ohno.T have developed an empirical model to evaluate SPM concentrations for the city of Nagoya, Japan. The model applies a linear relationship between the observed hourly SPM and $\mathrm{NO}_{\mathrm{x}}$ concentrations. There is a very good linear correlation between the two concentrations. In another paper (Tian J. and Chen D.) developed a semi-empirical model to predict hourly ground-level fine particulate matter (PM2.5) concentration in southern Ontario. The model is able to explain $65 \%$ of the variability in ground-level PM2.5 concentration. The model-predicted values of PM2.5 mass concentration are highly correlated with the actual observations. The root-mean-square error of the model is 6.1 $\mu \mathrm{g} / \mathrm{m}^{3}$. HoermannS et.al has done an empirical analysis on particulate matter PM10 in Graz. They developed two models, prediction model and regression model. An empirical model to predict suspended particulate matter from lakes is presented by Lindstrom.M. et al. It predicts lake typical SPMvalues from lake total phosphorous concentration (TP). The model is shown to be stable and can be very useful in predictive lake modeling.

\section{Methodology}

This study has been undertaken to review the air quality of two coal mines and to develop an empirical model to evaluate SPM concentration from ambient $\mathrm{NO}_{\mathrm{x}}$ concentrations and $\mathrm{SO}_{2}$ concentrations. One is Dhanbad colliery area Fig (1) and the other one is Magadh open cast mine Fig (2). The empirical methods are based on cross correlation of measured air quality data. These methods are reasonably reliable for predicting average SPM concentration. Dhanbad already has a network of continuous monitoring stations.

The area of study, Jharia coal fields is located in the heart of Dhanbad district in Jharkhand. Jharia encompasses an area of 9077.15 hectares and supports a population of 426415. Jharia coal fields are one among the few sources of prime coking coal in India. Mining is the most dominant industrial activity producing 24 million tons of coal every year. The coal mines studied included both open cast and underground mines. The major activities causing pollution are excavation works, explosion and transportation of coal. The major pollutants are SPM, sulphur dioxide and nitrogen oxides. The coal produced from this place is important for many heavy industries like iron \&steel, power generation etc. As a result there is an increased production year after year.

During all these years due to mining and allied activities, air pollution has taken its toll on the people and environment so much that even an hour outside will result in stains all over the clothes. It has also resulted in increased suffering and respiratory problems mainly asthma, nausea, inflammation of respiratory tracts, deposition of dust in the lungs and eye irritation. 


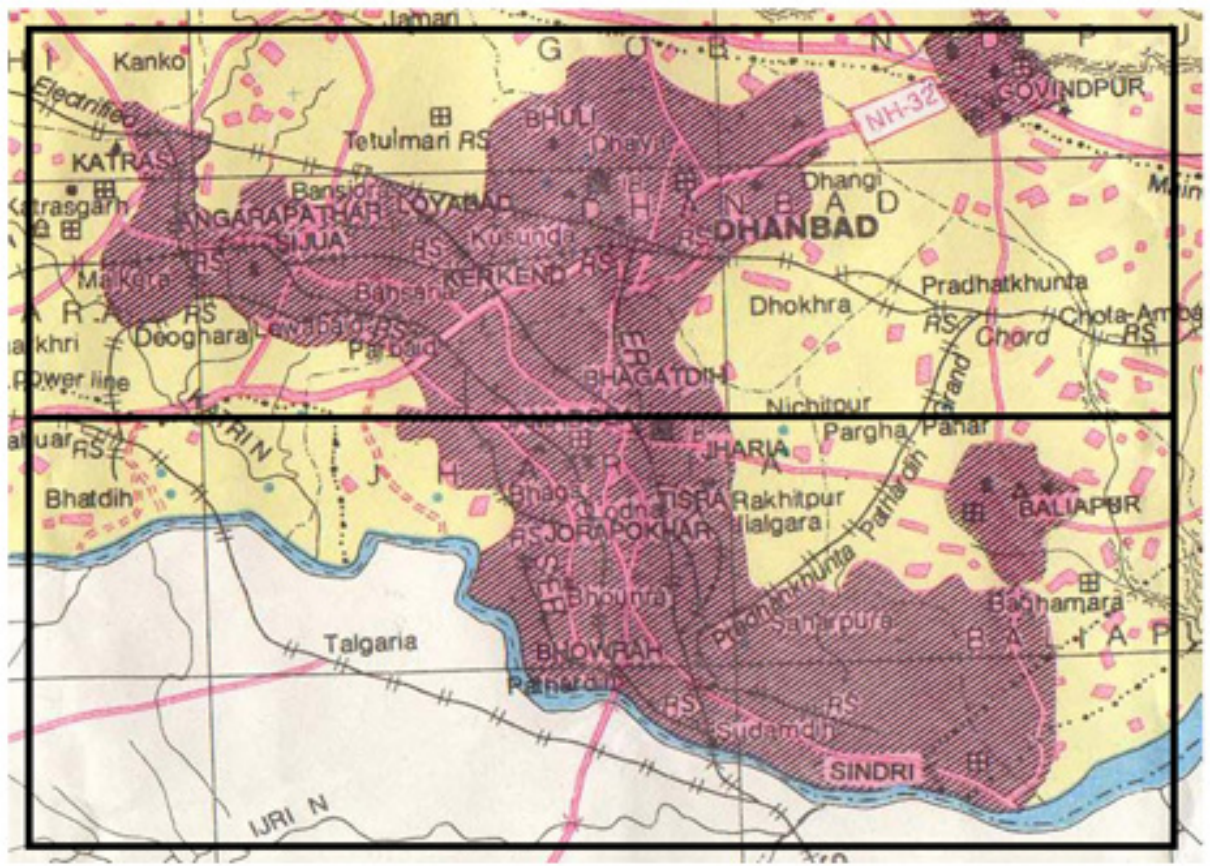

Map showing area under study. Upper portion- Part A \& Lower portion-Part B

Figure 1. Courtsey CMPDI,Ranchi, Jharkhand
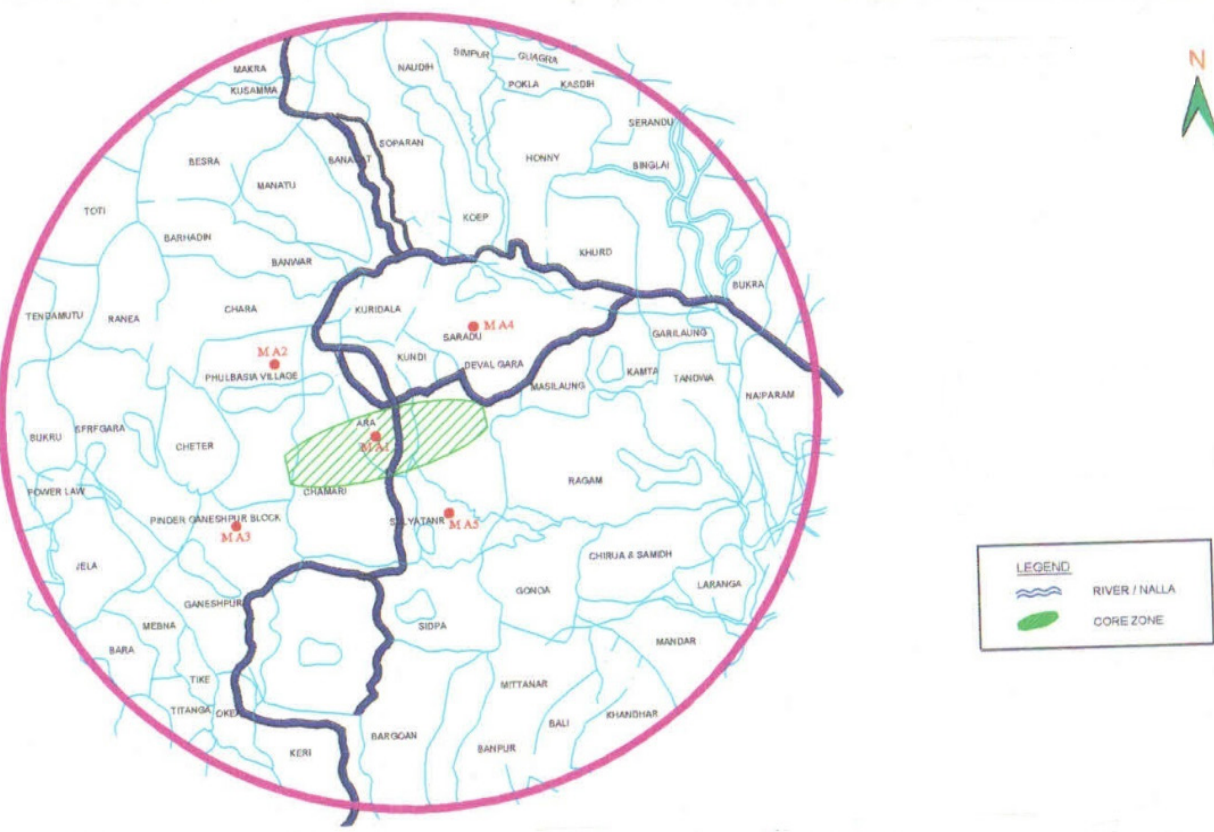

Figure 2. Courtsey CMPDI,Ranchi, Jharkhand

It is very expensive to setup a continuous monitoring station at each and every new site. So an empirical model which can predict concentration of one pollutant in terms of other pollutant will reduce the cost of monitoring in a new site.

The two types of sources that have impact on the air quality are mining sources and non-mining sources. The activities associated with mining which generate pollution are drilling, blasting, coal crushing, coal dumps, overburden dumps, coal transportation and coal loading on wagons. The main pollutants emitted from all above operations are particulate matter. The major non-mining activities contribute to air pollution are road and rail traffic, other industries like fire brick, coke manufacturing units and burning of fuel for domestic use.

Data from various monitoring stations around the colliery area were collected. The data was collected from the area with different topographic conditions to get a true set of varied results, which would give representative results. The data collected consists of concentration of SPM, $\mathrm{NO}_{\mathrm{x}}$ and 
$\mathrm{SO}_{2}$ by ambient air sampling.

The area under study was divided into two parts, part A and part B. Linear relationships have been developed between observed hourly SPM and $\mathrm{NO}_{\mathrm{x}}$ and $\mathrm{SPM}$ and $\mathrm{SO}_{2}$ concentrations for each part individually and for whole area based on monitoring network. These linear relationships are then used to evaluate the coefficients of the linear equation. The correlations between SPM and $\mathrm{SO}_{2}$ are shown in Figs 3(a),3(b)\&3(c).The correlations between SPM and $\mathrm{NO}_{\mathrm{x}}$ are shown in Figs 3(d),3(e)\&3(f)

Magadh opencast coal mine is situated in the North Karanpura Coalfields in Jharkhand. It has a rated capacity of 12.0 MTY. It is characterized by more or less flat terrain with gentle undulations. The project area is divided into two zones. Core zone is the area which consists of quarry, OB dumps, infrastructures etc. Buffer zone comprises of the area within a radial distance of $10 \mathrm{Km}$ from the core zone. Sampling stations are located in the Ara village (core zone), Phulbasia village and Ganeshpu village on the left of the core zone and Saradhu village and Sulyatnar village on the right of the core zone. The notations for these villages which are shown in Fig 2 are $\mathrm{MA}_{1}$ (Ara village), $\mathrm{MA}_{2}$ (Phulbasia village), $\mathrm{MA}_{3}\left(\right.$ Ganeshpu village), $\mathrm{MA}_{4}$ (Saradhu village) andMA (Sulyatnar village.) The air quality data collected are concentration of SPM, $\mathrm{NO}_{\mathrm{x}}$ and $\mathrm{SO}_{2}$ by ambient air sampling. Linear relationships have been developed between observed hourly SPM and $\mathrm{NO}_{\mathrm{x}}$ and $\mathrm{SPM}$ and $\mathrm{SO}_{2}$ concentrations for Ara, for the villages Phulbasia and Ganeshpu combined and for the villages Saradhu and Sulyatnar combined. The correlations between SPM and $\mathrm{SO}_{2}$ are shown in Figs 4(a),4(b)\&4(c). The correlations between SPM and $\mathrm{NO}_{x}$ are shown in Figs 4(d), 4(e)\&4(f).

\section{Correlation between concentrations of SPM and $\mathrm{SO}_{2}$ for Dhanbad Colliery}

Part A

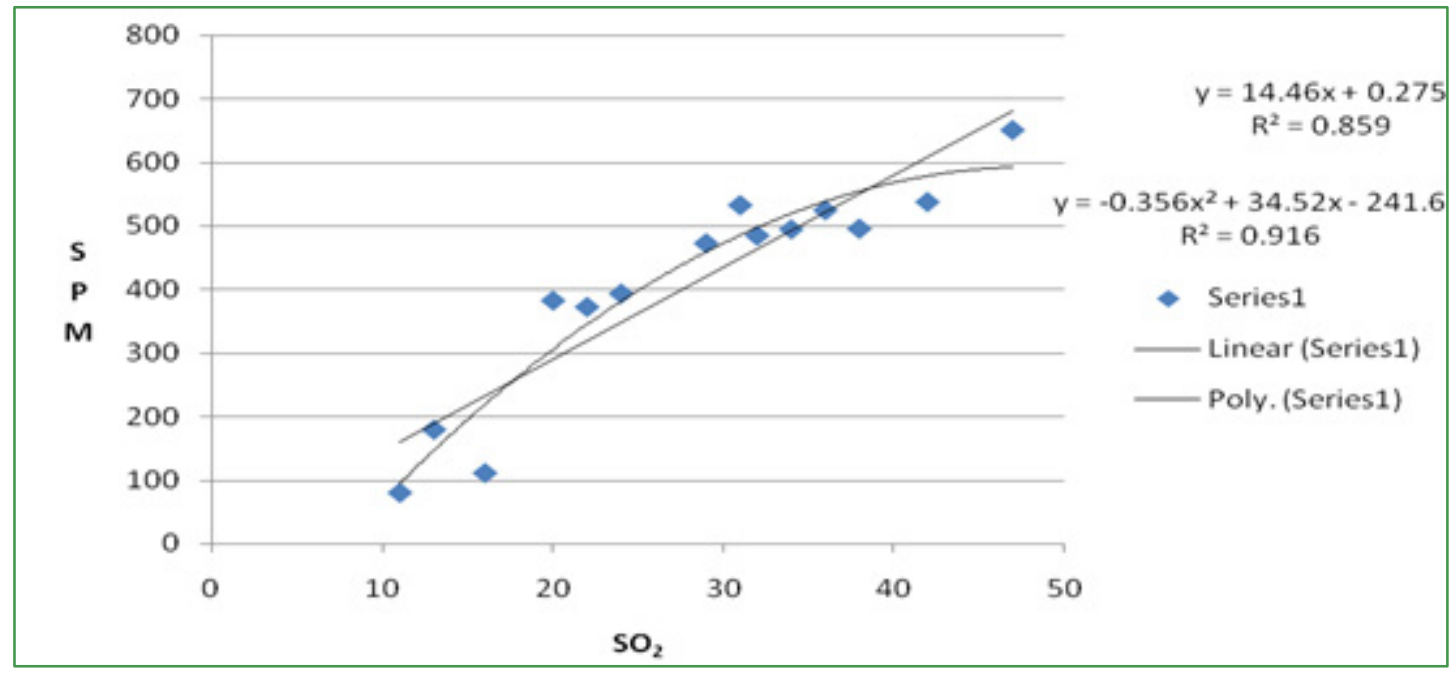

Figure 3(a)

Part B

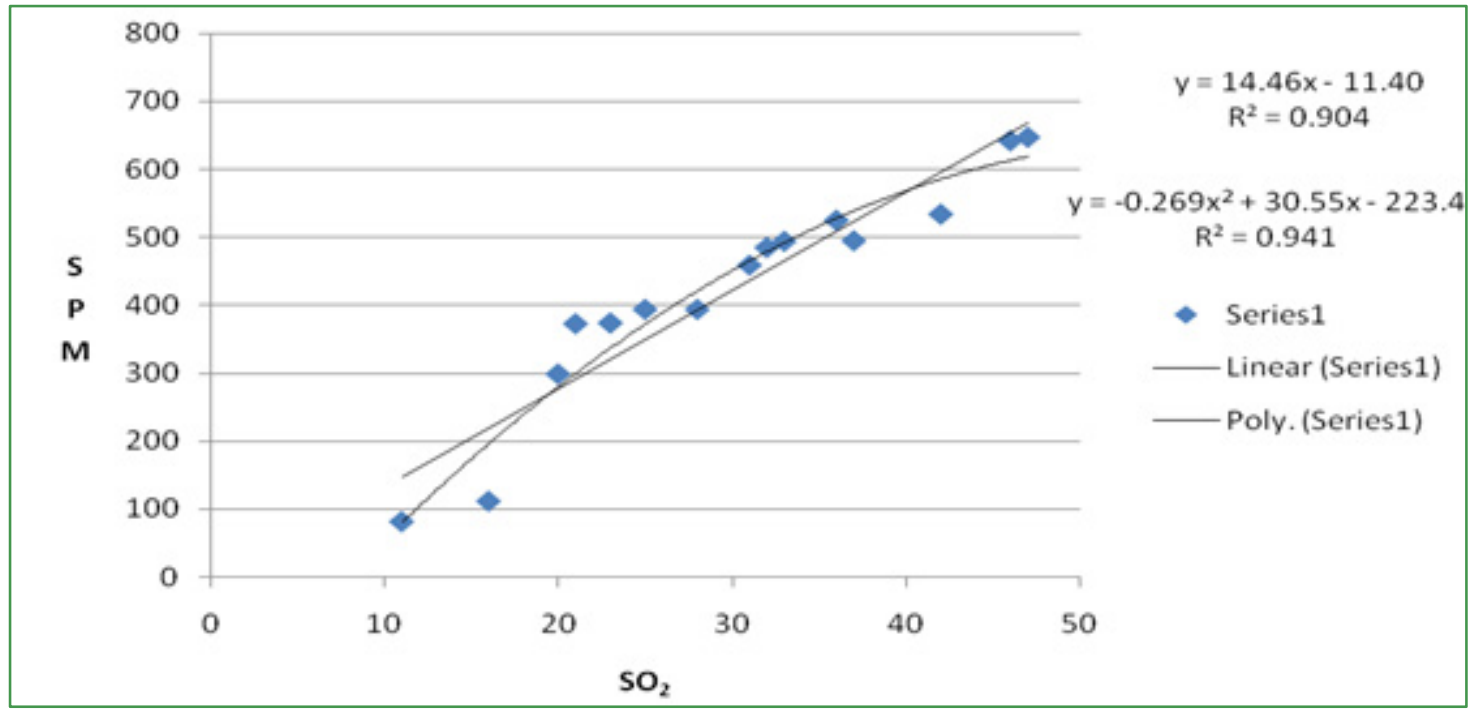

Figure 3(b) 
Part A-B Combined.

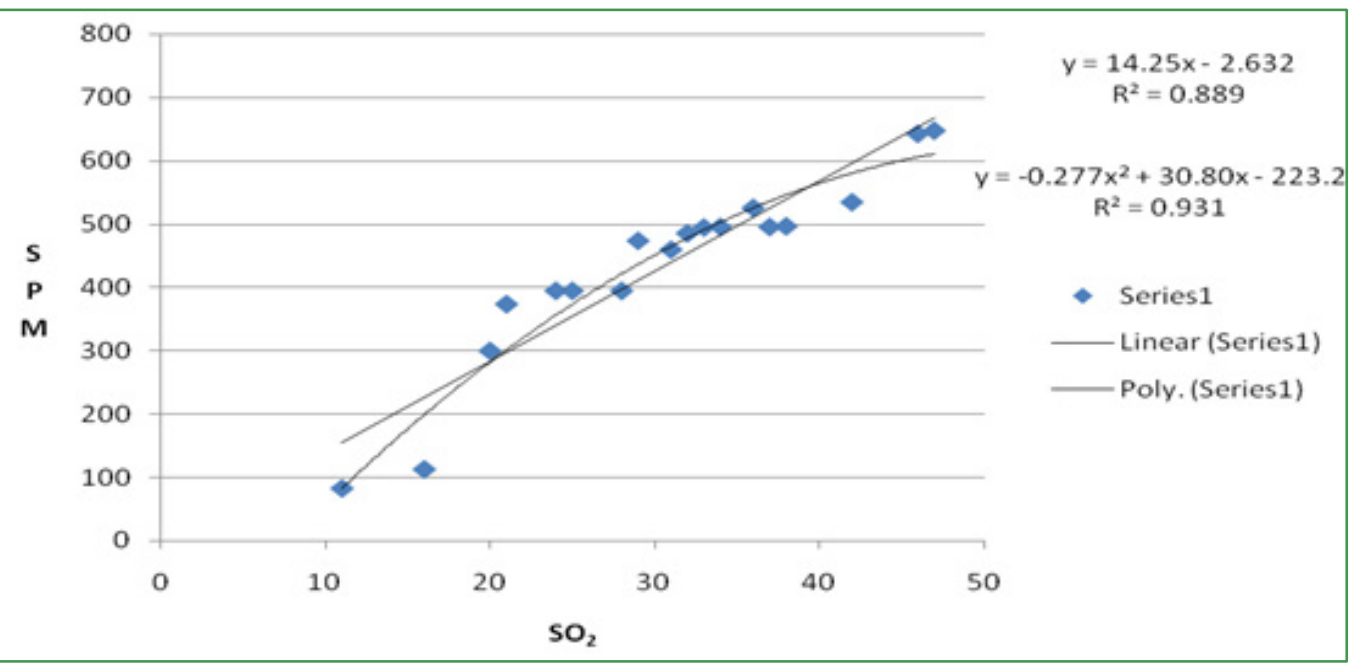

Figure 3(c)

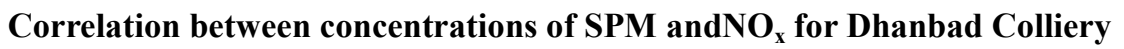

Part A

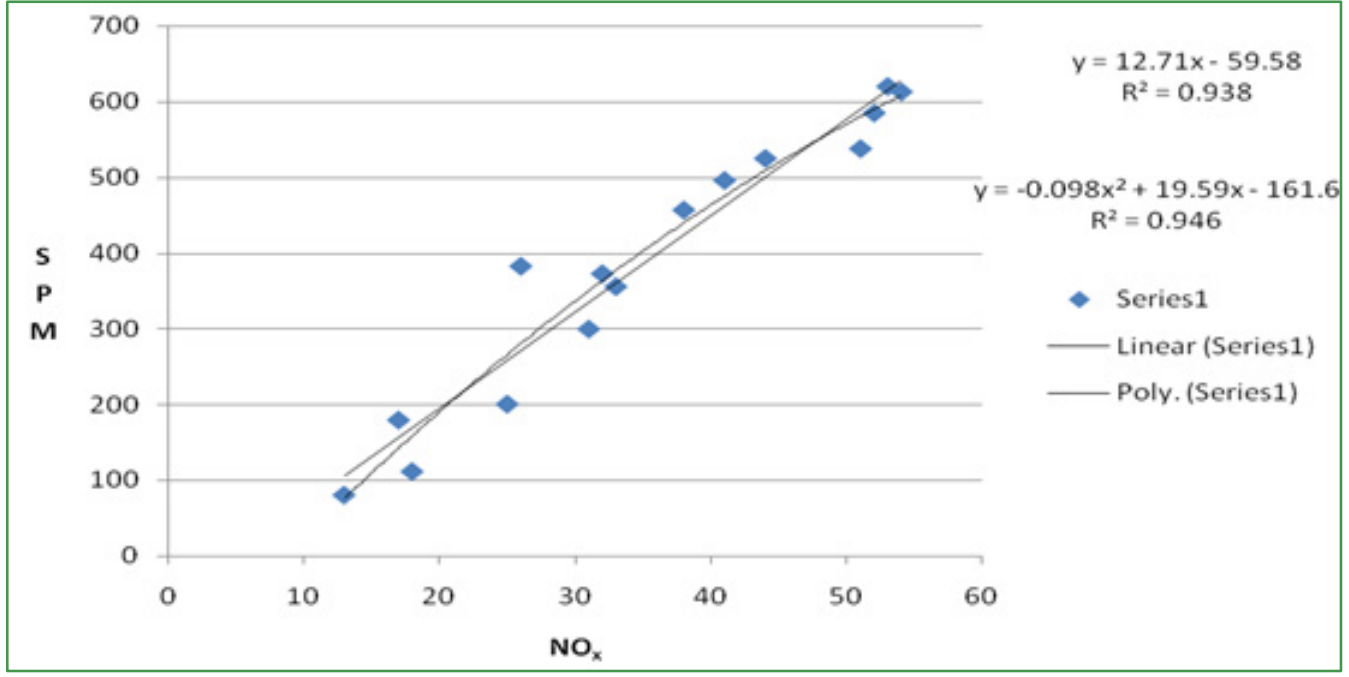

Figure 3(d)

Part B

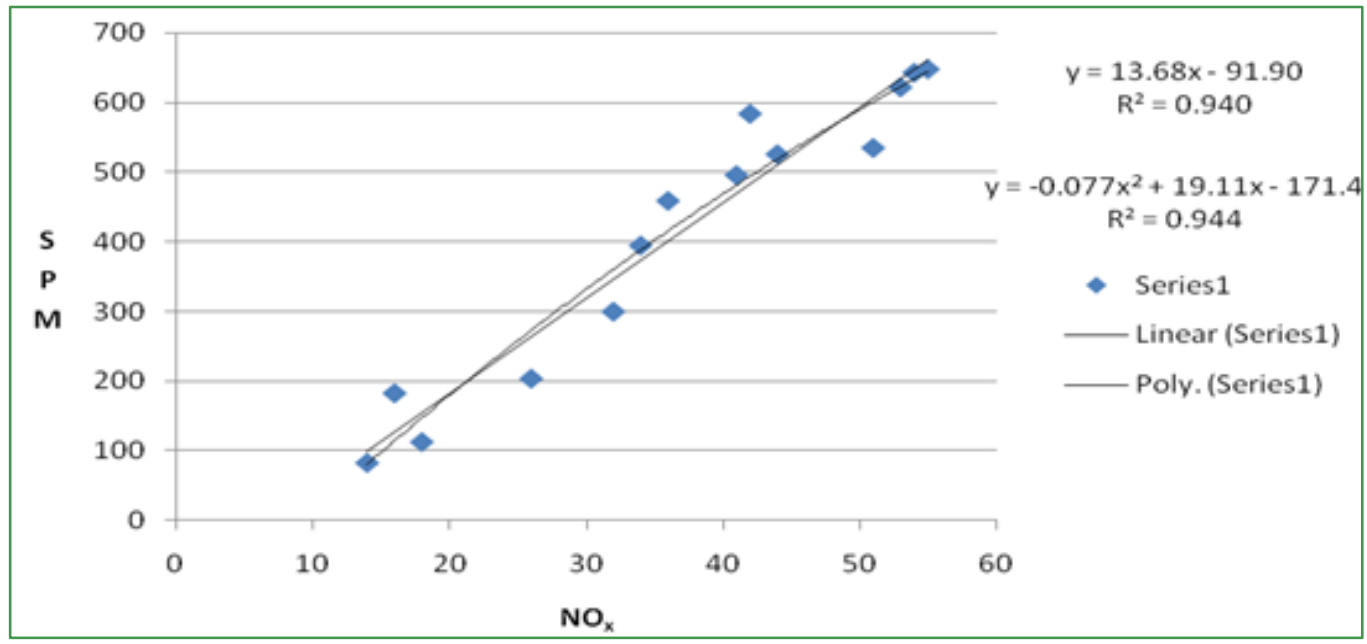

Figure 3(e 
Part A-B combined

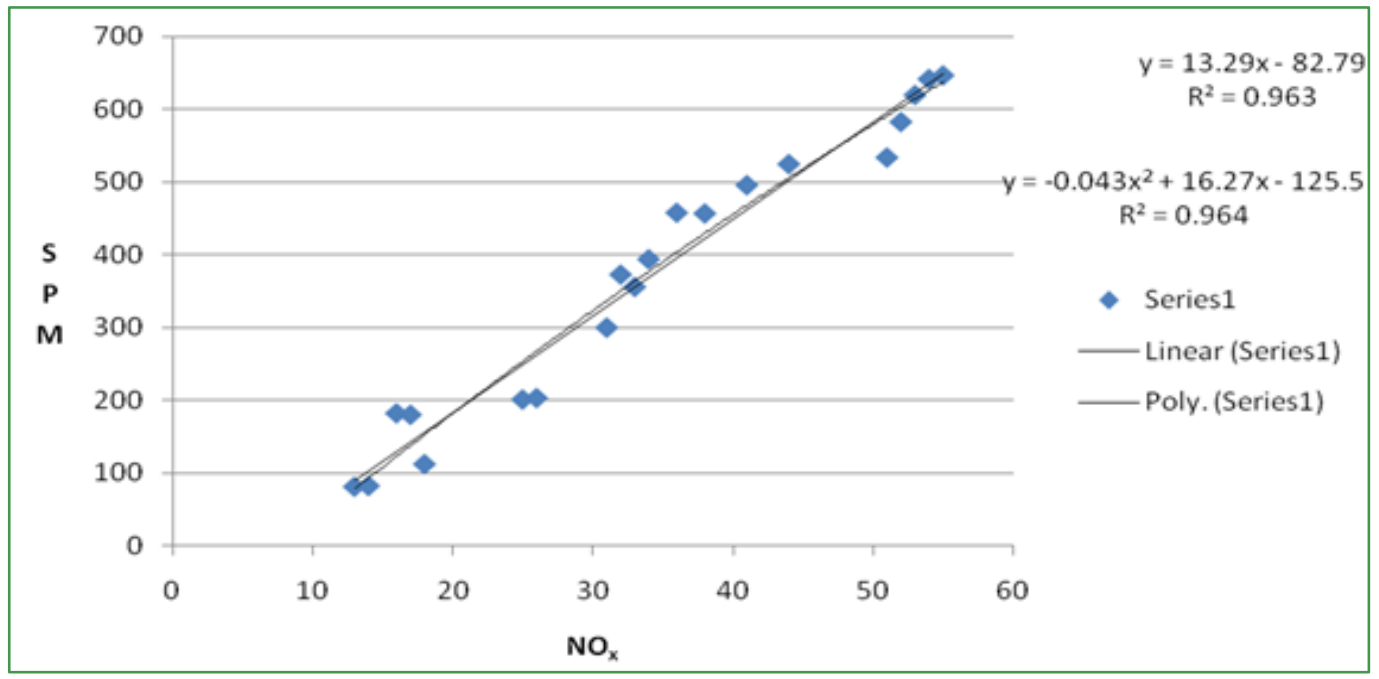

Figure 3(f)

Correlation between concentrations of SPM and $\mathrm{SO}_{2}$ for Magadh Opencast mine

ARA village

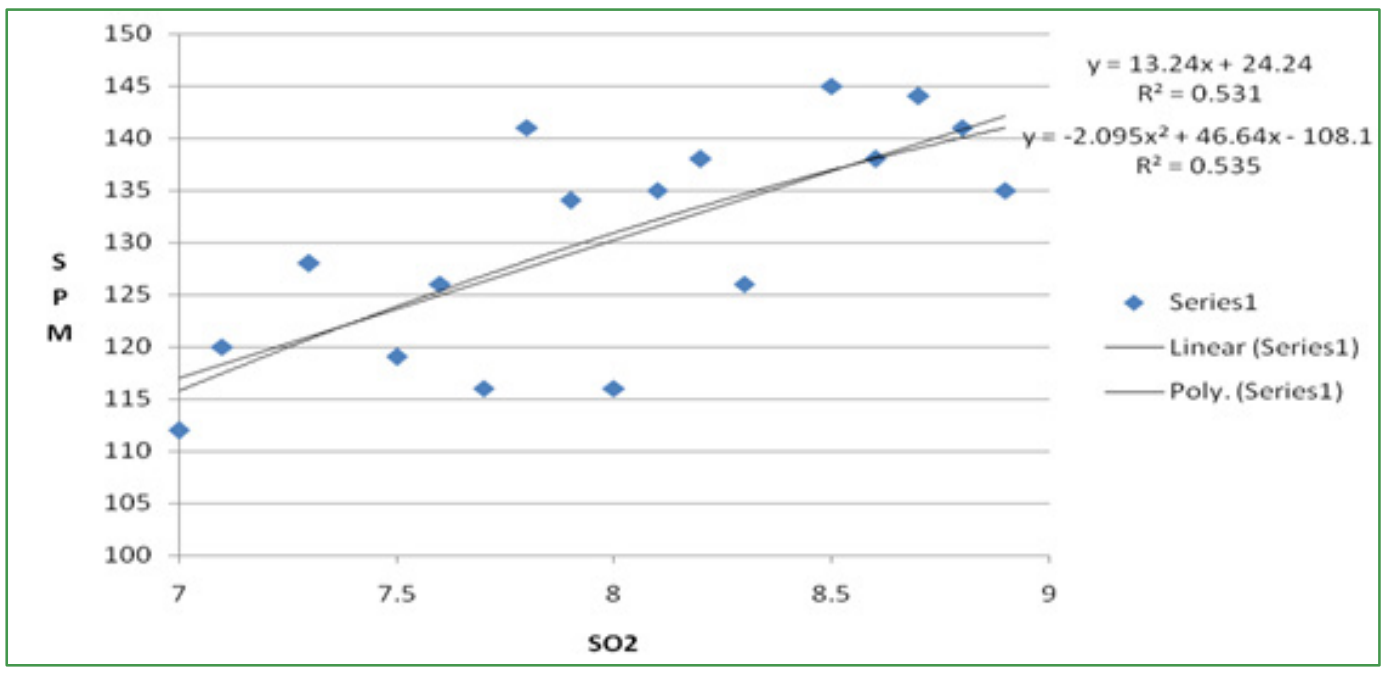

Figure 4(a)

PHULBASIA \& GANESHPUR villages

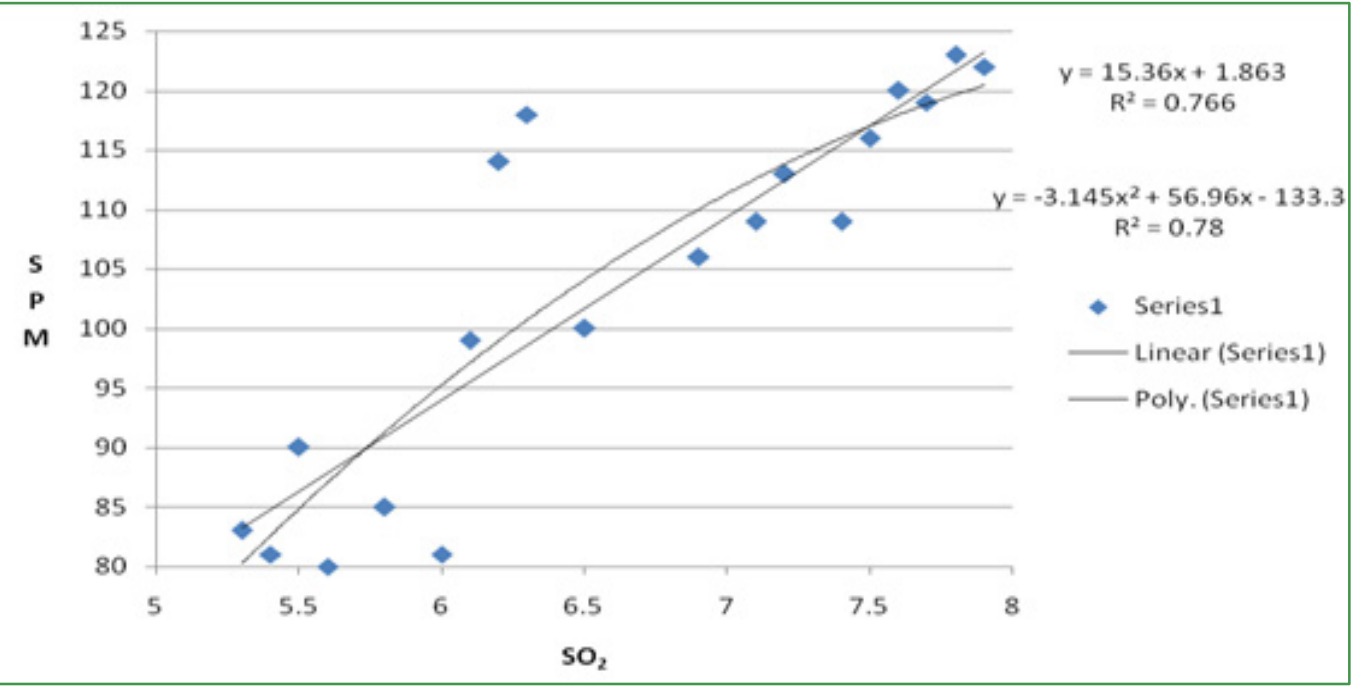

Figure 4(b) 
SARADU \& SULYATANR villages

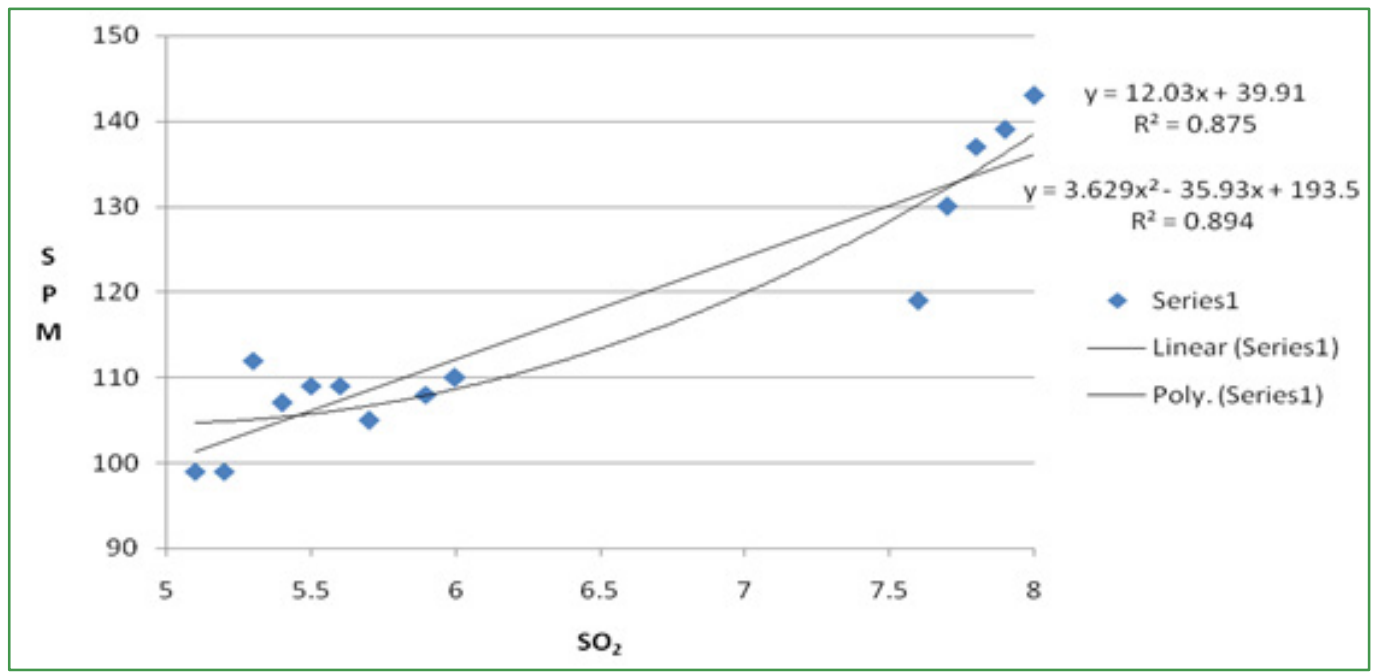

Figure 4(c)

Correlation between concentrations of SPM andNO ${ }_{x}$ for Magadh Opencast mine

ARA village

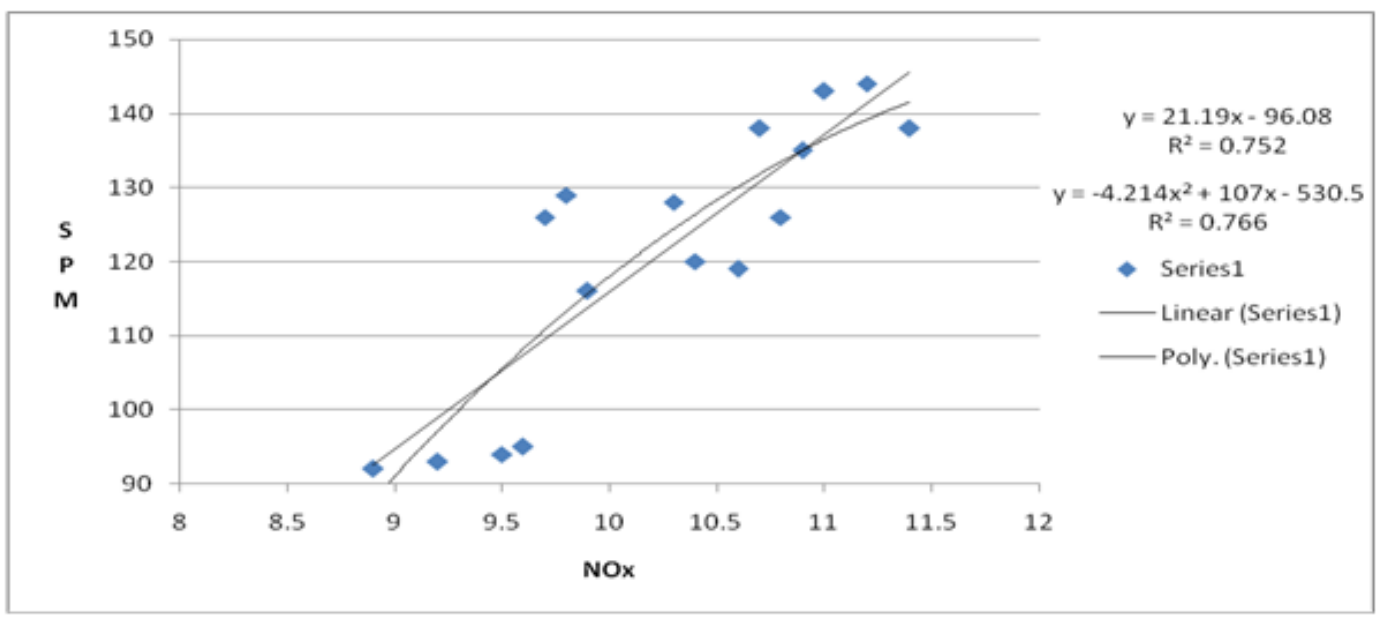

Figure 4(d)

PHULBASIA \& GANESHPUR villages

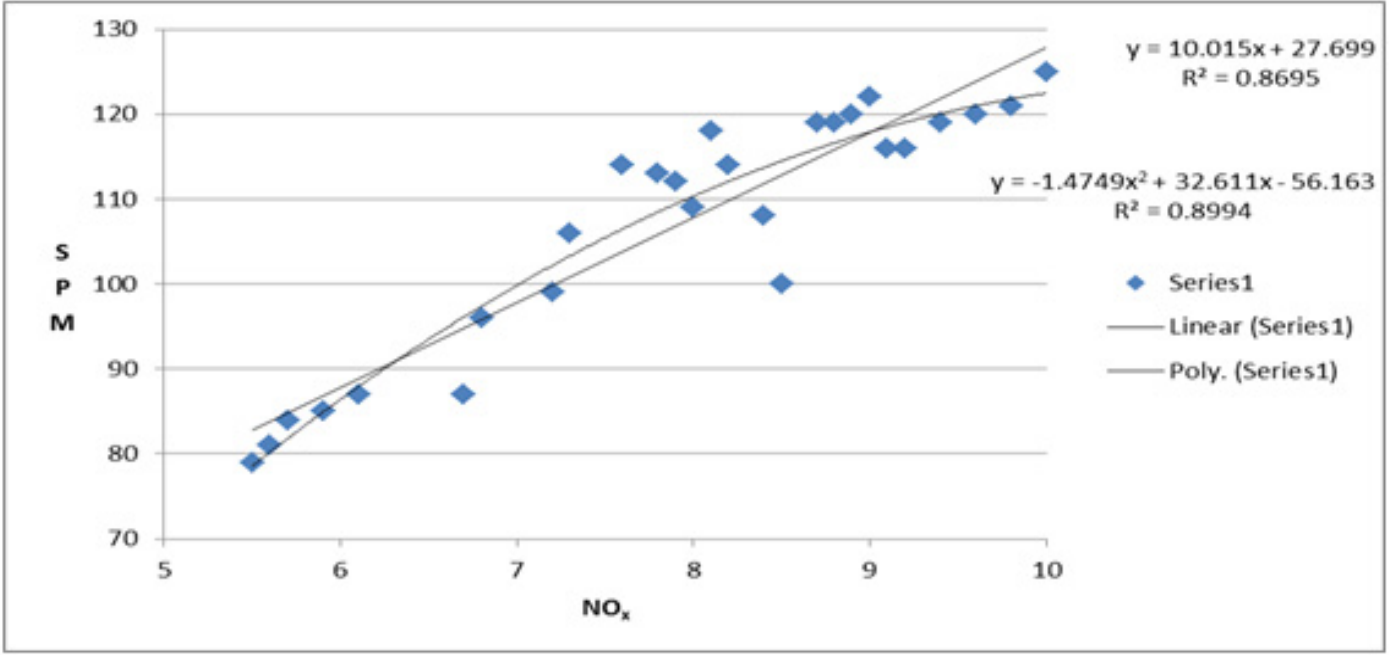

Figure 4(e) 


\section{SARADU \& SULYATANR villages}

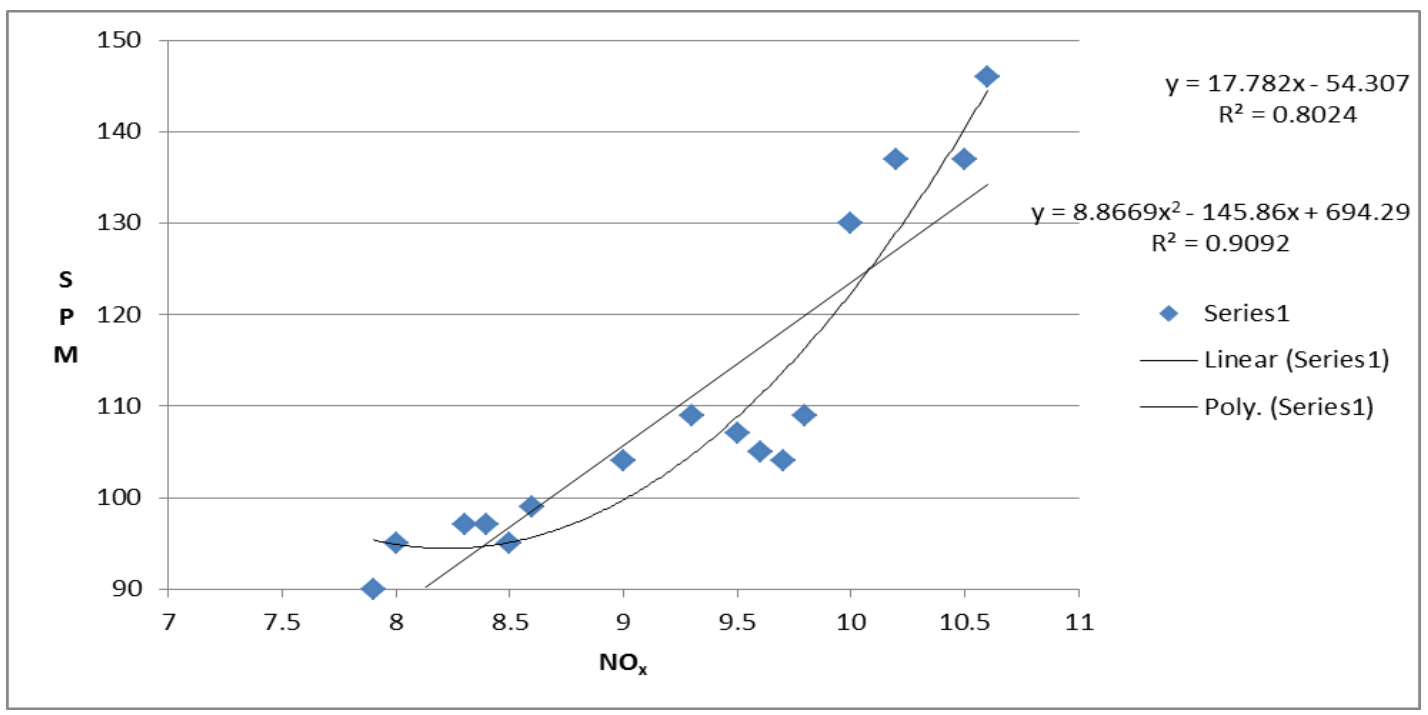

Figure 4(f)

Correlations obtained are summarized in Table 1 and Table 2

\section{Dhanbad Colliery}

Table 1.

\begin{tabular}{|c|c|c|c|c|c|}
\hline \multicolumn{7}{|c|}{ Relation between $\mathrm{SO}_{2}$ and SPM } \\
\hline Sl.No. & Linear & $\mathrm{R}^{2}$ & Polynomial & $\mathrm{R}^{2}$ & Area \\
\hline 1 & $\mathrm{y}=14.46 \mathrm{x}+0.275$ & 0.859 & $\mathrm{y}=-0.356 \mathrm{x}^{2}+34.52 \mathrm{x}-241.6$ & 0.916 & Part A \\
\hline 2 & $\mathrm{y}=14.46 \mathrm{x}-11.40$ & 0.904 & $\mathrm{y}=-0.269 \mathrm{x}^{2}+30.55 \mathrm{x}-223.4$ & 0.941 & Part B \\
\hline 3 & $\mathrm{y}=14.25 \mathrm{x}-2.632$ & 0.889 & $\mathrm{y}=-0.277 \mathrm{x}^{2}+30.80 \mathrm{x}-223.2$ & 0.931 & PartA-B \\
\hline \multicolumn{7}{|c|}{ Relation between $\mathrm{NO}_{\mathrm{x}}$ and SPM } \\
\hline 4 & $\mathrm{y}=12.71 \mathrm{x}-59.58$ & 0.938 & $\mathrm{y}=-0.098 \mathrm{x}^{2}+19.59 \mathrm{x}-161.6$ & 0.946 & Part A \\
\hline 5 & $\mathrm{y}=13.68 \mathrm{x}-91.90$ & 0.940 & $\mathrm{y}=-0.077 \mathrm{x}^{2}+19.11 \mathrm{x}-171.4$ & 0.944 & Part B \\
\hline 6 & $\mathrm{y}=13.29 \mathrm{x}-82.79$ & 0.963 & $\mathrm{y}=-0.043 \mathrm{x}^{2}+16.27 \mathrm{x}-125.5$ & 0.964 & PartA-B \\
\hline
\end{tabular}

\section{Magadh Opencast Mines}

Table 2.

\begin{tabular}{|c|c|c|c|c|c|}
\hline \multicolumn{6}{|c|}{ Relation between $\mathrm{SO}_{2}$ and SPM } \\
\hline Sl.No. & Linear & $\mathrm{R}^{2}$ & Polynomial & $\mathrm{R}^{2}$ & Area \\
\hline 1 & $y=13.24 x+24.24$ & 0.531 & $y=-2.095 x^{2}+46.64 x-108.1$ & 0.535 & Ara \\
\hline 2 & $y=15.36 x+1.863$ & 0.766 & $y=3.145 x^{2}+56.96 x-133.3$ & 0.780 & $\begin{array}{l}\text { Phulbasia\& } \\
\text { Ganeshpur }\end{array}$ \\
\hline 3 & $\mathrm{y}=12.03 \mathrm{x}+39.91$ & 0.875 & $\mathrm{y}=3.629 \mathrm{x}^{2}-35.93 \mathrm{x}+193.5$ & 0.931 & Saradu\& Sulyatanr \\
\hline \multicolumn{6}{|c|}{ Relation between $\mathrm{NO}_{\mathrm{x}}$ and SPM } \\
\hline 4 & $y=21.19 x-96.08$ & 0.752 & $y=-4.214 x^{2}+107 x-530.5$ & 0.766 & Ara \\
\hline 5 & $y=10.01 x+27.69$ & 0.869 & $y=-1.474 x^{2}+32.61 x-56.16$ & 0.944 & $\begin{array}{c}\text { Phulbasia\& } \\
\text { Ganeshpur }\end{array}$ \\
\hline 6 & $y=17.78 x-54.30$ & 0.802 & $\mathrm{y}=8.866 \mathrm{x}^{2}-145.8 \mathrm{x}+694.2$ & 0.909 & Saradu\& Sulyatanr \\
\hline
\end{tabular}

Where $\mathrm{y}=\mathrm{SPM}$ concentration $\left(\mu \mathrm{g} / \mathrm{m}^{3}\right)$

$\mathrm{x}=\mathrm{SO}_{2}$ concentration $\left(\mu \mathrm{g} / \mathrm{m}^{3}\right) / \mathrm{NOx}$ concentration $\left(\mu \mathrm{g} / \mathrm{m}^{3}\right)$ 


\section{SPM Concentration by Gaussian-Plume Method}

Meteorological data during the above period are collected for Dhanbad colliery and Magadh opencast mines.

The meteorological data collected are wind speed, temperature, cloud cover etc. The concentration of dust due to mining activities is calculated using Gaussian-plume equation ( Hanadi.S.et al). The general Gaussian -plume equation is

$$
C_{(X, Y, Z)}=\frac{Q}{\pi \sigma_{Y} \sigma_{Z} \bar{u}} \exp -\left\{\left[\frac{h^{2}}{2{\sigma_{Z}}^{2}}\right]+\left[\frac{y^{2}}{2{\sigma_{Y}}^{2}}\right]\right\}
$$

where

$\mathrm{C}=$ Concentration of the pollutant $\left(\mathrm{g} / \mathrm{m}^{3}\right)$

$\mathrm{Q}=$ Emission rate $(\mathrm{gm} / \mathrm{sec})$

$\sigma_{\mathrm{y}}, \sigma_{\mathrm{z}}=$ dispersion coefficient $(\mathrm{m})$

$\mathrm{u} \quad=$ wind speed $(\mathrm{m} / \mathrm{s})$

$\mathrm{x}, \mathrm{y}, \mathrm{z}=$ distances from the source in three planes $(\mathrm{m})$

$\mathrm{h} \quad=$ height of plume $(\mathrm{m})$

As the site selected is a coalmine, sources are considered to be located on level ground.

Hence, $\mathrm{h}=0$

Therefore concentration is calculated using equation given below

$$
C_{(X, Y, 0)}=\frac{Q}{\pi \sigma_{Y} \sigma_{Z} \bar{u}} \exp \left[-\frac{1}{2}\left(\frac{y}{\sigma_{Y}}\right)^{2}\right]
$$

The dispersion coefficients are calculated using Pasquill-Gifford method. The most widely used correlations for $\sigma_{Y}$ and $\sigma_{Z}$ were given by Gifford (1961) based on Pasquill stability categories. These correlations are commonly referred to as the Pasquill-Gifford curves or Pasquill-Gifford Turner curves and are given by Turner (1970).The stability class to calculate the dispersion coefficients is determined by Pasqull-Gifford method based on solar insolation and solar elevation. Central Mining Research Institute, Dhanbad, an organization under CSIR, took up an S\&T study titled "Development of Emission Factor for Various Open Cast Mining Operations" funded by Ministry of Environment \& Forest, Government of India. The mathematical expression developed by them is used in this project (Chaulya.S.K. et al). These expressions have been validated by a series of field observations of dust generation of all individual activities.

\section{Results and Discussions}

The general equation for Dhanbad coal area can be summarized as follows

Relation between $\mathrm{SO}_{2}$ and $\mathrm{SPM}$

1. $\mathrm{y}=14.46 \mathrm{x}-11.40$ (Linear)

2. $y=-0.269 x^{2}+30.55 x-223.4$ (Polynomial)

Relation between $\mathrm{NO}_{\mathrm{x}}$ and SPM
1. $\mathrm{y}=13.29 \mathrm{x}-82.79$ (Linear)

2. $\mathrm{y}=-0.043 \mathrm{x}^{2}+16.27 \mathrm{x}-125.5$ (Polynomial)

The general equation for Magadh coal mines can be summarized as follows

Relation between $\mathrm{SO}_{2}$ and $\mathrm{SPM}$

1. $\mathrm{y}=12.03 \mathrm{x}+39.91$ (Linear)

2. $y=3.629 x^{2}-35.93 x+193.5$ (Polynomial)

Relation between $\mathrm{NO}_{\mathrm{x}}$ and SPM

1. $\mathrm{y}=10.01 \mathrm{x}+27.69$ (Linear)

2. $\mathrm{y}=-1.474 \mathrm{x}^{2}+32.61 \mathrm{x}-56.16$ (Polynomial)

A comparison is made between the concentrations obtained from the field using high volume samplers and concentration calculated using the empirical formulae. There is only $10 \%$ variation between the observed values and the values predicted by the empirical formulae. The comparisons between the two values for Dhanbad and Magadh mines are shown in Table 3 and Table 4.Comparison is also made between concentration of SPM calculated by Gaussian Plume method, empirical formulae and measured by high volume samplers.(Table $5 \&$ Table 6 ). The results do not vary much.

\section{Dhanbad Colliery}

\begin{tabular}{|c|c|c|c|c|}
\hline \multirow[t]{2}{*}{ S1.No. } & \multicolumn{2}{|c|}{$\mathrm{SPM}$ and $\mathrm{SO}_{2}$} & \multicolumn{2}{|c|}{$\mathrm{SPM}$ and $\mathrm{NO}_{\mathrm{x}}$} \\
\hline & $\begin{array}{c}\text { Observed } \\
\text { Value }\left(\mu \mathrm{g} / \mathrm{m}^{3}\right)\end{array}$ & $\begin{array}{c}\text { Predicted } \\
\text { Value }\left(\mu \mathrm{g} / \mathrm{m}^{3}\right)\end{array}$ & $\begin{array}{c}\text { Observed } \\
\text { Value }\left(\mu \mathrm{g} / \mathrm{m}^{3}\right)\end{array}$ & $\begin{array}{c}\text { Predicted } \\
\text { value }\left(\mu \mathrm{g} / \mathrm{m}^{3}\right)\end{array}$ \\
\hline 1 & 300 & 294 & 300 & 322 \\
\hline 2 & 356 & 395 & 356 & 357 \\
\hline 3 & 485 & 457 & 373 & 339 \\
\hline 4 & 496 & 482 & 394 & 373 \\
\hline 5 & 435 & 477 & 620 & 658 \\
\hline 6 & 651 & 664 & 525 & 530 \\
\hline 7 & 395 & 402 & 395 & 360 \\
\hline 8 & 496 & 536 & 496 & 491 \\
\hline 9 & 394 & 402 & 457 & 427 \\
\hline 10 & 355 & 392 & 619 & 620 \\
\hline 11 & 459 & 430 & 642 & 628 \\
\hline 12 & 495 & 526 & 394 & 376 \\
\hline 13 & 525 & 512 & 525 & 502 \\
\hline 14 & 299 & 279 & 495 & 467 \\
\hline 15 & 642 & 665 & 583 & 598 \\
\hline 16 & 647 & 646 & 621 & 625 \\
\hline 17 & 374 & 362 & 616 & 632 \\
\hline 18 & 458 & 475 & 300 & 337 \\
\hline 19 & 485 & 475 & 534 & 590 \\
\hline 20 & 583 & 541 & 642 & 635 \\
\hline
\end{tabular}

Table 3 


\section{Magadh Opencast Mines}

Table 4

\begin{tabular}{|c|c|c|c|c|}
\hline Sl.No. & \multicolumn{2}{|c|}{$\mathrm{SPM}$ and $\mathrm{SO}_{2}$} & \multicolumn{2}{|c|}{ SPM and $\mathrm{NO}_{\mathrm{x}}$} \\
\hline & $\begin{array}{c}\text { Observed } \\
\text { Value }\left(\mu \mathrm{g} / \mathrm{m}^{3}\right)\end{array}$ & $\begin{array}{c}\text { Predicted } \\
\text { Value }\left(\mu \mathrm{g} / \mathrm{m}^{3}\right)\end{array}$ & $\begin{array}{c}\text { Observed } \\
\text { Value }\left(\mu \mathrm{g} / \mathrm{m}^{3}\right)\end{array}$ & $\begin{array}{c}\text { Predicted } \\
\text { value }\left(\mu \mathrm{g} / \mathrm{m}^{3}\right)\end{array}$ \\
\hline 1 & 143 & 146 & 141 & 137 \\
\hline 2 & 120 & 125 & 129 & 126 \\
\hline 3 & 125 & 133 & 85 & 87 \\
\hline 4 & 123 & 133 & 109 & 98 \\
\hline 5 & 120 & 107 & 122 & 118 \\
\hline 6 & 114 & 113 & 99 & 112 \\
\hline 7 & 120 & 125 & 130 & 133 \\
\hline 8 & 94 & 104 & 95 & 107 \\
\hline 9 & 141 & 141 & 119 & 124 \\
\hline 10 & 130 & 133 & 130 & 133 \\
\hline 11 & 109 & 105 & 96 & 101 \\
\hline 12 & 105 & 108 & 84 & 85 \\
\hline 13 & 128 & 128 & 121 & 125 \\
\hline 14 & 120 & 130 & 126 & 124 \\
\hline 15 & 141 & 136 & 125 & 124 \\
\hline 16 & 110 & 105 & 109 & 100 \\
\hline 17 & 123 & 121 & 87 & 87 \\
\hline 18 & 121 & 123 & 108 & 114 \\
\hline 19 & 105 & 93 & 100 & 114 \\
\hline 20 & 96 & 106 & 119 & 121 \\
\hline
\end{tabular}

\section{Dhanbad Colliery}

Table 5

\begin{tabular}{|c|c|c|c|}
\hline S1 No. & \multicolumn{3}{|c|}{ SPM concentration obtained by } \\
\hline & $\begin{array}{c}\text { Empirical } \\
\text { Formulae }\left(\mu \mathrm{g} / \mathrm{m}^{3}\right)\end{array}$ & $\begin{array}{c}\text { HighVolume } \\
\text { Sampler }\left(\mu \mathrm{g} / \mathrm{m}^{3}\right)\end{array}$ & $\begin{array}{c}\text { Gaussian } \\
\text { Plume } \\
\text { Method }\left(\mu \mathrm{g} / \mathrm{m}^{3}\right)\end{array}$ \\
\hline 1 & 294 & 300 & 304 \\
\hline 2 & 357 & 356 & 352 \\
\hline 3 & 339 & 373 & 354 \\
\hline 4 & 482 & 496 & 500 \\
\hline 5 & 477 & 435 & 470 \\
\hline 6 & 530 & 525 & 516 \\
\hline 7 & 402 & 395 & 410 \\
\hline 8 & 491 & 496 & 496 \\
\hline 9 & 402 & 394 & 407 \\
\hline 10 & 512 & 525 & 530 \\
\hline 11 & 279 & 299 & 286 \\
\hline 12 & 376 & 394 & 380 \\
\hline 13 & 625 & 621 & 628 \\
\hline 14 & 475 & 458 & 470 \\
\hline 15 & 475 & 485 & 478 \\
\hline 16 & 625 & 621 & 627 \\
\hline 17 & 665 & 642 & 680 \\
\hline 18 & 646 & 647 & 650 \\
\hline & & & \\
\hline & & & 527 \\
\hline
\end{tabular}

\section{Magadh Opencast Mines}

Table 6

\begin{tabular}{|c|c|c|c|}
\hline S1 No. & \multicolumn{3}{|c|}{ SPM concentration obtained by } \\
\hline & $\begin{array}{c}\text { Empirical } \\
\text { Formulae }\left(\mu \mathrm{g} / \mathrm{m}^{3}\right)\end{array}$ & $\begin{array}{c}\text { HighVolume } \\
\text { Sampler }\left(\mu \mathrm{g} / \mathrm{m}^{3}\right)\end{array}$ & $\begin{array}{c}\text { Gaussian Plume } \\
\text { Method }\left(\mu \mathrm{g} / \mathrm{m}^{3}\right)\end{array}$ \\
\hline 1 & 146 & 120 & 147 \\
\hline 2 & 125 & 120 & 124 \\
\hline 3 & 137 & 141 & 145 \\
\hline 4 & 126 & 129 & 120 \\
\hline 5 & 107 & 120 & 117 \\
\hline 6 & 122 & 118 & 117 \\
\hline 7 & 113 & 114 & 119 \\
\hline 8 & 104 & 94 & 102 \\
\hline 9 & 141 & 141 & 146 \\
\hline 10 & 133 & 130 & 140 \\
\hline 11 & 128 & 128 & 140 \\
\hline 12 & 130 & 120 & 128 \\
\hline 13 & 124 & 125 & 128 \\
\hline 14 & 100 & 109 & 110 \\
\hline 15 & 87 & 87 & 80 \\
\hline 16 & 106 & 96 & 100 \\
\hline 17 & 114 & 108 & 130 \\
\hline 18 & 93 & 105 & 90 \\
\hline & & & \\
\hline
\end{tabular}

\section{Conclusions}

It can be seen from the graphs that there is a similarity in the empirical relations between concentrations of SPM and $\mathrm{SO}_{2}$ and $\mathrm{SPM}$ and $\mathrm{NO}_{\mathrm{x}}$ as the value of $\mathrm{R}^{2}$ is almost same. Since the value of $R^{2}$ is near to unity in most cases, there is not much variation between observed and predicted values. The concentration of SPM is calculated using Gaussian-Plume method which is the most popular kinetic approach used for Indian conditions. There is not much variation between the values obtained by empirical formulae and Gaussian Plume method. Using measured spatial distributions of $\mathrm{NOx} \& \mathrm{SO}_{2}$ concentration from various source categories, estimation of SPM concentration is possible. The empirical model developed can be used for other coal fields having similar characteristics.

\section{REFERENCES}

[1] Dastoor, A.P., Pudykiewicz, J., 1996. A numerical global meteorological sulfur transport model and its application to arctic air pollution. Atmospheric Environment 30, 1501-1513.

[2] Binkowski, F.S., Ching, J.K.S., 1996. Modelling fine particulate mass and visibility using the EPA regional particulate models. Ninth Joint Conference on Applications of 
Air Pollution Meteorology with the A and WMA, January 28-February 2, 1996, Boston, 565-569.

[3] Saltbones, J., Foss, A., Bartnicki, J., 1998. Norwegian meteorological institute's real-time dispersion model snap (severe nuclear accident program): runs for ETEX and ATMES II experiments with different meteorological input. Atmospheric Environment 32, 4277-4283

[4] Cohn, R.D., Eder, B.K., Leduc., S.K., Dennis, R.L., 2001. Development of an aggregation and episode selection scheme to support the models-3 community multiscale air quality model. Journal of Applied Meteorology 40, 210-228.

[5] Vardoulakis, S., Fisher, B.E.A., Pericleous, K., Gonzalez-Flesca, N., 2003. Modelling air quality in street canyons: a review. Atmospheric Environment 37, 155-182.

[6] Karim M.M. and Ohno.T.(2000), "Air quality planning and empirical model to evaluate SPM concentrations" J.Environ.Eng 126, 1116-1124

[7] Tian.J. and ChenD.(2010), "A semi-empirical model for predicting hourly ground-levelfine particulate matter(PM2.5) concentration in southern Ontario from satellite remote sensing and ground-based meteorological measurements"
Remote Sensing of Environment,114, 221-229

[8] Hoermann S.,Pfeiler B. and Stadlober E.(2005),“Analysis and Prediction of Particulate Matter PM10 for the Winter Season in Graz " Australian Journal of Statistics, 34(4) 307-326

[9] Lindstrom M.,Hakanson L., Abrahamsson O.,Johansson H.(1999), "An empirical model for prediction of lake water suspended particulate matter" Ecological Modelling 121, 185-198

[10] Hanadi. S. Rifer, Fariba Mehdizadeh, Paul Laware, "Simulating Air Quality Using a Gaussian Dispersion Model", Environmental Policy Issues, Environmental Institute of Houston, University of Houston, Texas, pp.35-37

[11] S.K.Chaulya, M.K.Chakraborty, M.Ahmad, R.S.Singh, C. Bondyopadhay, G.C.Mondal and D.Pal,(2002) "Development of Formulae to Determine Emission Rate from various Mining Operations", Water, Air and Soil Pollution, Vol.140, No.s1-4, pp.21-55.

[12] S.K.Chaulya, M.Ahmad, R.S.Singh, K.Bondyopadhay, C. Bondyopadhay and G.C.Mondal(2003), "Validation of Two Air Quality Models for Indian Conditions", Environmental Monitoring and Assessment, Vol.82, No.1, pp.23-43. 